\title{
ANALITIKA
}

Available online http://ojs.uma.ac.id/index.php/ analitika

\section{Efektivitas Pelatihan Komunikasi untuk Meningkatkan Keterampilan Komunikasi Siswa Kejuruan Jurusan Akomodasi Perhotelan}

\section{Effectiveness of Communication Training to Increase Communication skills of Vocational Students Majoring in Hospitality Accomodation}

\author{
Andi Ahmad Ridha
}

Magister Psikologi Profesi, Fakultas Psikologi, Universitas Airlangga, Indonesia *Corresponding author: a.ahmad.ridha-2015@psikologi.unair.ac.id

\begin{abstract}
Abstrak
Penelitian ini bertujuan untuk mengetahui efektivitas pelatihan komunikasi efektif terhadap keterampilan komunikasi siswa SMK jurusan akomodasi perhotelan. Penelitian ini menggunakan metode kuantitatif eksperimen dengan desain one group pretest posttest design. Subjek penelitian terdiri dari 6 orang siswa SMK jurusan akomodasi perhotelan yang memiliki keterampilan komunikasi yang buruk. Intervensi yang diberikan kepada subjek yaitu berupa pelatihan komunikasi efektif. Instrumen penelitian yang digunakan berupa soal evaluasi belajar dan lembar observasi rating scale. Analisis data dilakukan secara deskriptif dan menggunakan analisis statistik wilcoxon test. Hasil penelitian menunjukkan bahwa terdapat peningkatan pengetahuan dan keterampilan komunikasi yang dimiliki siswa sebelum dan setelah diberikan pelatihan komunikasi efektif. Temuan penelitian ini dapat dijadikan rujukan dalam mengembangkan keterampilan komunikasi siswa SMK jurusan akomodasi perhotelan.
\end{abstract}

Kata kunci: Pelatihan, Komunikasi Efektif, Keterampilan Komunikasi, Siswa

\begin{abstract}
This study aimed to determine the effectiveness of effective communication training on communication skills of vocational students majoring in hospitality accommodation. This research uses quantitative experimental method with one group pretest posttest design. Six students from vocational school majoring in hospitality accommodation with poor communication skill, participated in this research. An effective communication training was given as an intervention in improving communication skills. Learning evaluationand observation rating scale were used to reveal the communication skills. Data analysis was done descriptively and using statistical analysis of wilcoxon test. The results showed that there was an increase in knowledge and communication skills possessed before and after students were given effective communication training. The findings of this research can be used as a reference in developing communication skills of vocational students in hospitality accommodation.
\end{abstract}

Keywords: Effective, Communication Training, Communication Skills, Student.

How to Cite: Ridha, A. A., (2018), Efektivitas Pelatihan Komunikasi untuk Meningkatkan Keterampilan Komunikasi Siswa Kejuruan Jurusan Akomodasi Perhotelan. Analitika, 10 (1): 14 - 20 


\section{PENDAHULUAN}

Akomodasi perhotelan merupakan salah satu jurusan di SMK Negeri 8 Surabaya yang menekankan keahlian dalam menguasai informasi dan kemampuan tentang pengelolaan dan penyelenggaraan jasa perhotelan. Jurusan akomodasi perhotelan mencakup 5 bidang kompetensi yang harus dikuasai oleh siswa yaitu bidang 1) house keeping, 2) front office, 3) laundry, 4) F\&B service, dan 5) F\&B product. Dalam proses pembelajaran, selain menilai kemampuan pemahaman/teori terhadap 5 bidang tersebut, penilaian juga dilakukan dengan melihat kemampuan siswa dalam mempraktikkan secara langsung ilmu yang didapatkannya, seperti cara siswa berkomunikasi dalam melayani tamu/ pengguna jasa, sikap siswa dalam merespon keluhan dan kebutuhan pengguna jasa, dan keterampilan siswa dalam memberikan informasi yang dibutuhkan oleh pengguna jasa.

Berko, Aitken, dan Wolvin (2010) mengemukakan bahwa komunikasi adalah proses sadar atau tidak disadari, disengaja atau tidak disengaja dimana perasaan dan gagasan diungkapkan sebagai pesan verbal dan/atau nonverbal, yang dikirim, diterima, dan dipahami. Komunikasi adalah sesuatu yang dinamis, kontinyu, ireversibel, interaktif, dan kontekstual. Selain itu, Arbi (2012) mengemukakan bahwa komunikasi adalah pertukaran pikiran atau gagasan secara verbal. Komunikasi adalah suatu proses dengan mana kita memahami dan dipahami oleh orang lain.

Hasil wawancara dengan beberapa guru akomodasi perhotelan menunjukkan bahwa terdapat kemampuan komunikasi adalah kompetensi inti yang harus dimiliki oleh siswa agar dapat berkarir dengan baik dalam dunia perhotelan dan hal tersebut sejak dini sudah harus disiapkan dan dimiliki oleh siswa. Berdasarkan observasi terhadap siswa-siswa akomodasi perhotelan saat proses pembelajaran (praktik kerja sebagai front office), terlihat bahwa siswa-siswa yang sedang praktik kurang mampu dalam melakukan komunikasi dengan baik saat melayani tamu, siswa-siswa terlihat kurang percaya diri/grogi saat berhadapan dengan tamu. Hal tersebut dibenarkan oleh guru yang mengajar bahwa siswa-siswa jurusan akomodasi perhotelan, cukup banyak yang kurang mampu berkomunikasi dan melayani tamu seperti yang sudah diajarkannya di dalam kelas.

Hal ini menunjukkan bahwa siswa kurang mampu menyampaikan pesan dan menerima pesan dalam melakukan komunikasi secara efektif. Fujishin (2009) menjelaskan bahwa dalam komunikasi terdapat tiga proses yaitu: 1) Sebuah proses, komunikasi adalah sebuah proses/ sesuatu yang terus berlanjut dan berubah; 2) Membuat pesan, kemampuan individu untuk menciptakan pesan dari dimensi komunikasi verbal dan non verbal; dan 3) Bertukar pesan, setelah memilih kata-kata, kalimat, dan isyarat nonverbal untuk membentuk pemikiran atau perasaan yang ingin individu komunikasikan, individu mengirim pesan ke penerima, yang memproses pesan dan memberikan tanggapan berupa umpan balik.

Sementara itu, hasil wawancara dengan beberapa siswa jurusan akomodasi perhotelan menunjukkan bahwa siswa cenderung merasa canggung 
ketika ada tamu yang berkunjung, siswa juga merasa sungkan untuk menyapa atau memulai percakapan dengan tamu/ sekedar menanyakan keperluan tamu, dan terkadang siswa merasa ingin berbicara kepada tamu tapi suaranya seperti tertekan untuk dikeluarkan sehingga seringkali siswa menyambut tamu dengan tersenyum saja. Rivers (2005) mengemukakan bahwa terdapat tujuh prinsip yang harus dimiliki oleh seseorang yang ingin meningkatkan kemampuannya dalam berkomunikasi yaitu: 1) Dengarkan lebih hati-hati dan responsif; 2) Jelaskan maksud percakapan individu dan minta persetujuan; 3) Ekspresikan diri dengan lebih jelas dan lengkap; 4) Terjemahkan keluhan (dan keluhan orang lain) kepada permintaan spesifik individu, dan jelaskan permintaan individu; 5) Ajukan pertanyaan lebih "terbuka" dan lebih kreatif; 6) Ungkapkan apresiasi lebih; dan 7) Jadikan komunikasi yang lebih baik menjadi bagian penting dalam kehidupan sehari-hari Anda.

Berdasarkan hasil asesmen yang diperoleh menunjukkan bahwa siswasiswa jurusan akomodasi perhotelan kurang mampu berkomunikasi secara efektif. Berdasarkan hasil observasi peneliti terhadap aktivitas siswa yang sedang melakukan praktik seperti sebagai front office terlihat bahwa siswa kurang tanggap dalam melayani tamu yang berkunjung, siswa berkomunikasi dengan logat kedaerahan yang masih terasa, kurang inisiatif bertanya pada tamu, kurang ekspresif, kurang ramah, dan antusias dalam menyambut/menyapa tamu. Selain itu, saat sedang praktik menggunakan alat-alat tertentu dalam jurusan akomodasi perhotelan, terlihat bahwa siswa kurang mampu berbicara dengan jelas, kurang baku, masih sering menggunakan istilah em, anu, eh, apa, dan siswa kurang mampu menyampaikan pesan/maksud pembicaraannya kepada orang lain seperti saat melakukan demonstrasi. Siswa-siswa lain yang mendengar justru semakin bingung. Ferguson (2009) mengemukakan bahwa komunikasi tidak hanya merupakan sebuah percakapan tapi bahasa tubuh juga adalah bentuk dari komunikasi. Individu terkadang mengabaikan bentuk komunikasi vital ini, yang berpotensi untuk menyampaikan sinyal positif dan negatif. Memberikan layanan pelanggan yang prima akan membantu perusahaan sukses dan hal tersebut hanya dapat diraih dengan melakukan komunikasi secara efektif. Kunci dari komunikasi yang sukses adalah persiapan yang hati-hati, tujuan yang jelas, pemahaman pendengar, dan penggunaan bahasa tubuh yang efektif.

Hasil wawancara dengan guru dan juga hasil kuesioner menunjukkan bahwa siswa terlihat kurang mampu melayani tamu dengan baik, kurang ramah, kurang ekspresif, kurang tanggap, kurang percaya diri, kurang memiliki inisiatif dalam melayani tamu, dan kurang mampu memberikan pelayanan prima seperti yang diharapkan oleh guru-guru. Sementara itu, hasil wawancara dengan beberapa siswa jurusan akomodasi perhotelan diketahui bahwa siswa cenderung merasa canggung ketika ada tamu yang berkunjung, siswa juga merasa sungkan untuk menyapa atau memulai percakapan dengan tamu/ sekedar menanyakan keperluan tamu, dan terkadang siswa merasa ingin berbicara kepada tamu tapi suaranya seperti 
tertekan dan susah untuk dikeluarkan sehingga seringkali siswa menyambut tamu dengan tersenyum saja.

Rivers (2005) mengemukakan bahwa agar tujuan dalam berkomunikasi dapat tercapai, maka individu dituntut agar dapat lebih banyak meluangkan waktu untuk jadi pendengar dan responsif, lebih ekspresif, nyatakan kembali maksud pembicaraan/ keluhan rekan bicara, mengajukan pertanyaan lebih terbuka dan lebih kreatif. Hal ini tidak terjadi pada siswa - siswa jurusan akomodasi perhotelan sehingga tujuan komunikasi yang dilakukan oleh siswa tidak tercapai.

Selain itu, dalam proses pembelajaran, terkadang siswa ingin bertanya kepada guru, namun siswa merasa susah untuk berbicara dan mengomunikasikan perasaannya kepada guru. Siswa merasa bahwa kesulitannya berkomunikasi menyebabkan ia memperoleh nilai yang rendah, minder, dan pada saat praktik ia tiba-tiba menjadi tidak tahu apa yang harus dilakukannya. Terkadang siswa sudah mempelajari apa hal-hal yang perlu dilakukan saat praktik tapi ketika berhadapan dengan situasi yang nyata seperti ketika tamu berkunjung, siswa merasa ingin berbicara tapi kesusahan menyampaikan apa yang ingin dikatakan. Lestari dan Maliki (2006) mengemukakan bahwa orang dalam berkomunikasi sering mengalami hambatan yang tidak dikehendaki, akan tetapi hal itu terjadi. Hambatan itu menjadikan komunikasi tidak efektif. Hambatan tersebut dapat terjadi karena adanya faktor-faktor tertentu seperti persepsi, status orang yang berkomunikasi, sikap defensif, perasaan negatif, asumsi, bahasa yang digunakan, tidak mampu mendengar, dan lingkungan yang kurang kondusif.

Berdasarkan permasalahan di atas, maka dapat disimpulkan bahwa diperlukan sebuah pelatihan bagi siswa sebagai bekal dalam melaksanakan peran sebagai siswa perhotelan yaitu pelatihan komunikasi efektif. Pelatihan yang diberikan kepada siswa diharapkan dapat menambah pengetahuan mengenai konsep dasar dalam berkomunikasi sehingga siswa semakin dapat memahami pentingnya melakukan komunikasi secara efektif. Siswa juga diharapkan dapat memiliki keterampilan dalam berkomunikasi secara efektif agar siswa dapat menjalankan tugas sebagai siswa perhotelan dengan lebih efektif, kreatif, dan percaya diri. Oleh karena itu, dengan pengetahuan, keterampilan, dan sikap yang dimiliki kelak diharapkan dapat meminimalkan permasalahan yang dikeluhkan oleh guru dan siswa dalam proses belajar mengajar pada jurusan akomodasi perhotelan.

Adapun tujuan dari penelitian ini untuk mengetahui efektivitas intervensi berupa pelatihan komunikasi efektif terhadap keterampilan komunikasi siswa. Hipotesis dalam penelitian ini yaitu pelatihan komunikasi dapat meningkatkan keterampilan siswa jurusan akomodasi perhotelan dalam berkomunikasi.

\section{METODE PENELITIAN}

Penelitian ini menggunakan pendekatan kuantitatif dengan metode penelitian eksperimental. Rancangan penelitiannya berupa one group pretest posttest design. Populasi dalam penelitian ini adalah siswa SMK Negeri 8 Surabaya jurusan akomodasi perhotelan yang 
memiliki keterampilan berkomunikasi dengan kategori rendah. Dari 35 orang subjek penelitian yang mengalami permasalahan, hanya 15 orang yang menyatakan bersedia mengikuti pelatihan komunikasi. Pada pelaksanaan pelatihan, yang menghadiri pelatihan hingga tuntas hanya 6 orang subjek. Oleh karena itu, sampel dalam penelitian ini adalah sebanyak 6 orang siswa (4 laki-laki, 2 perempuan) yang dilakukan dengan teknik purposive sampling.

Instrumen penelitian yang digunakan terdiri atas dua jenis yaitu soal evaluasi belajar yang terdiri atas 25 aitem pertanyaan dalam bentuk pilihan ganda dengan koefisien reliabilitas sebesar 0,866 cronbach's alpha untuk mengukur pengetahuan subjek tentang materi pelatihan komunikasi yang diberikan dan menggunakan observasi rating scale yang terdiri atas 8 aitem perilaku yang terbagi ke dalam dua aspek yaitu aspek verbal dan non verbal yang menggambarkan keterampilan dalam berkomunikasi.

Adapun intervensi yang diberikan berupa pelatihan komunikasi efektif. Pelatihan dilaksanakan dalam waktu 2 hari (06.30-12.40 WIB) pada tanggal 1-2 Agustus 2017. Pelatihan terbagi ke dalam 3 sesi yaitu 1) pemberian materi tentang konsep dasar dalam berkomunikasi; 2) materi tentang keterampilan berkomunikasi; dan 3) materi tentang pengembangan komunikasi. Pelatihan dirancang dalam bentuk ceramah, studi kasus, dan role-play.

Metode analisis data yang digunakan dalam penelitian ini berupa analisis data secara deskriptif untuk mendapatkan gambaran mengenai perbedaan nilai mean yang diperoleh sebelum dan setelah diberikan pelatihan dan menggunakan analisis statistik wilcoxon test untuk mengetahui efektivitas pemberian pelatihan terhadap keterampilan siswa dalam berkomunikasi.

\section{HASIL DAN PEMBAHASAN}

Berdasarkan hasil analisis statistik dengan uji wilcoxon, diketahui bahwa terdapat perbedaan pengetahuan subjek sebelum dan setelah diberikan pelatihan komunikasi, yang dilihat dari nilai signifikansi $0,028<0,05$. Hal tersebut juga tergambar dari perbedaan nilai rata-rata yang diperoleh sebelum dan setelah pelatihan. Nilai rata-rata yang diperoleh sebelum pelatihan yaitu sebesar 9.00 dengan nilai minimum 6 dan nilai maksimum 12 yang diperoleh subjek dari hasil pretest. Adapun nilai rata-rata yang diperoleh setelah pelatihan yaitu sebesar 18.67 dengan nilai minimum 15 dan nilai maksimum 22 yang diperoleh subjek dari hasil posttest.

Selain itu, selama subjek melakukan roleplay, peneliti bersama dengan rekan peneliti mengobservasi subjek, setelah diberikan feedback terkait penampilannya, maka subjek diminta untuk melakukan roleplay lagi untuk melihat apakah subjek mampu mengambil pelajaran dari feedback yang diberikan. Hasil observasi menunjukkan bahwa lima dari enam orang subjek menunjukkan peningkatan dalam berkomunikasi sementara satu subjek lainnya masih terbata-bata dalam berkomunikasi saat pelaksanaan roleplay.

Hasil observasi secara ringkas ditampilkan dalam grafik berikut ini: 


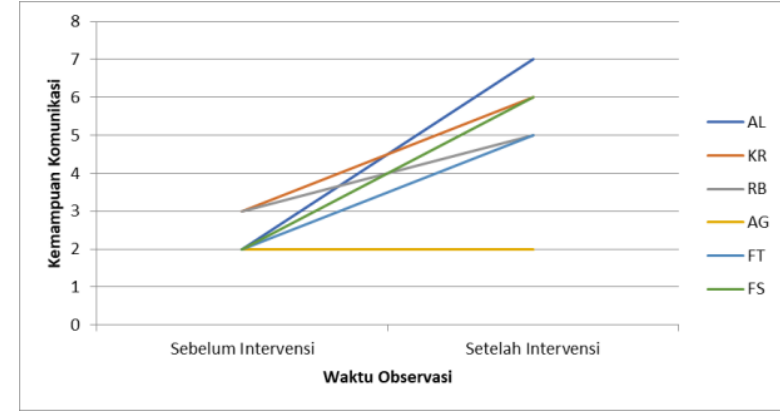

Gambar 1. Grafik Hasil Observasi Kemampuan Komunikasi Peserta Pelatihan

Hasil penelitian ini sejalan dengan penelitian sebelumnya yang dilakukan oleh Martiani (2016) bahwa pelatihan komunikasi terbukti efektif dalam meningkatkan keterampilan ibu dan anak dalam berkomunikasi. Setelah diberikan pelatihan, ibu dan anak menjadi terbuka dalam berkomunikasi satu sama lain. Selain itu, hasil penelitian ini juga mendukung penelitian sebelumnya yang dilakukan oleh Haq (2016) bahwa pelatihan komunikasi secara signifikan berpengaruh terhadap kemampuan komunikasi mahasiswa tingkat akhir program studi psikologi pada Universitas Mulawarman. Hasil penelitian ini juga sejalan dengan penelitian sebelumnya yang dilakukan oleh Wardani (2012) bahwa pelatihan komunikasi dapat meningkatkan efikasi diri mahasiswa.

Hasil penelitian ini menunjukkan bahwa komunikasi adalah sesuatu yang bersifat menyeluruh yang meliputi aspek verbal dan non verbal yang saling memengaruhi antar satu individu dengan individu lainnya. Hal tersebut tergambar dari hasil observasi terhadap subjek penelitian selama pelaksanaan roleplay. Kelima subjek dapat menunjukkan perubahan yang cukup signifikan dalam melaksanakan roleplay, sementara satu subjek lainnya merasa bahwa pemahamannya tentang komunikasi bertambah namun subjek masih merasa sulit mengekspresikan dirinya. Subjek masih merasa perlu belajar lebih banyak dan berlatih berkomunikasi dengan baik serta lebih percaya pada diri sendiri. Barker (2011) mengemukakan bahwa komunikasi memiliki tiga prinsip penting yaitu 1) komunikasi terjadi secara terusmenerus, seperti sebuah proses. Individu selalu memperbaharui pemahamannya maka komunikasi akan terus dilakukan untuk menjadi efektif; 2) komunikasi merupakan sesuatu yang rumit, apapun yang telah dipahami oleh individu merupakan sesuatu yang telah dikomunikasikan. Hal tersebut berarti segala sesuatu yang diamati, tidak hanya kata-kata yang diucapkan seseorang tapi suara dan gerak tubuh manusia; dan 3) komunikasi bersifat kontekstual. Arti komunikasi dipengaruhi oleh lima konteks yang berbeda, yaitu psikologis, relasional, situasional, lingkungan, dan kultural.

Selain itu, berdasarkan hasil evaluasi kegiatan pelatihan, dapat diketahui bahwa secara keseluruhan subjek merasa puas dengan kegiatan pelatihan yang diadakan selama 2 hari. Hanya saja subjek merasa kurang nyaman dengan kondisi ruang pelatihan yang diadakan di ruang UKS karena pada hari pertama, suasana pelatihan cukup terganggu dengan adanya siswa yang pingsan dan dilarikan ke UKS dan siswasiswa lainnya mondar-mandir di dalam UKS yang cukup mengganggu jalannya kegiatan. Selain itu, siswa-siswa di luar ruang UKS terlalu ribut, didukung oleh kondisi ruang UKS yang tembus pandang dari luar sehingga banyak orang dari luar yang mengintip ke dalam ruang UKS yang 
membuat para subjek tidak nyaman, namun secara keseluruhan dari segi materi yang disampaikan, subjek merasa sangat bermanfaat dan berguna untuk meningkatkan kemampuannya dalam berkomunikasi.

\section{SIMPULAN}

Berdasarkan hasil penelitian yang telah dilakukan, maka dapat disimpulkan bahwa terdapat peningkatan pengetahuan dan keterampilan yang dimiliki siswa dalam berkomunikasi sebelum dan setelah diberikan intervensi berupa pelatihan komunikasi efektif. Temuan dari penelitian ini dapat ditindaklanjuti sebagai dasar dalam mengembangkan keterampilan komunikasi siswa SMK jurusan akomodasi perhotelan dengan menambah waktu dan memperkaya materi pelatihan sesuai dengan setting jurusan akomodasi perhotelan.

\section{DAFTAR PUSTAKA}

Arbi, A. (2012). Psikologi komunikasi dan tabligh. (Edisi ke-1). (Cetakan ke-1). Jakarta: Amzah.

Barker, A. (2011). Improve your communication skills. (Revised 2nd Edition). London: Koganpage.
Berko, R., Aitken, J. E., \& Wolvin, A. (2010). ICOMM: interpersonal concepts and competencies foundations of interpersonal communication. America: Rowman \& Littlefield Publishers, Inc.

Ferguson. (2009). Communication skills. (3rd Edition). New York: Ferguson Publishing.

Fujishin, R. (2009). Creating communication: Exploring and expanding your fundamental communication skills. (2nd Edition). America: Rowman \& Littlefield Publishers, Inc.

Haq, K. (2016). Pengaruh pelatihan komunikasi efektif terhadap kemampuan komunikasi (Mahasiswa tingkat akhir program studi psikologi Universitas Mulawarman Samarinda). Ejournal Psikologi, 4(4): 408418.

Lestari, E., \& Maliki, MA. (2006). Komunikasi yang efektif. Jakarta: Lembaga Administrasi Negara RI.

Martiani. (2016). Efektivitas pelatihan keterampilan komunikasi untuk meningkatkan kualitas hubungan iburemaja. Naskah Publikasi. Program Studi Magister Psikologi Profesi, Fakultas Psikologi, Universitas Muhammadiyah Surakarta.

Rivers, D. (2005). The seven challenges, a workbook and reader about communicating more cooperatively. (Revised 3rd Edition). USA: Trafford Publishing.

Wardani, D. S. K. (2012). Pengaruh pelatihan komunikasi efektif untuk meningkatkan efikasi diri mahasiswa. Jurnal Psikologi Pendidikan dan Perkembangan, 1(2): 1-7. 